\title{
From Buddhist Story to Heroic Epic: A Comparative Study of the Epic of Geser and the Mulian Story
}

\author{
JUNG KWANGHUN ${ }^{1 *}$ and KIM HYUNJU² \\ ${ }^{1}$ Geumgang University, 522, Sangwol-ro, Nonsan-si, Chungcheongnam-do, Korea \\ ${ }^{2}$ Hankuk University of Foreign Studies, 81, Oedae-ro, Mohyeon-eup, Cheoin-gu, Yongin-si, Gyeonggi-do, Korea
}

Received: July 16, 2018 • Accepted: December 23, 2020

(C) 2021 The Author(s)

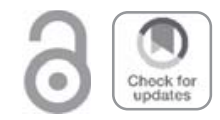

\begin{abstract}
This paper compares narrative modification in the Mongolian heroic epic The Epic of Geser with that of the Buddhist Mulian story. The Mulian story, in which the protagonist saves his mother from the underworld gained widespread popularity in its time. Mulian Bianwen from the Tang dynasty, presents the scenes from the story in a very dramatic manner. The Mongolian Geser epic uses this motif but adapts the story to fit the characteristics of a heroic epic for nomadic people. Heroic epics must contain motifs that depict the image of their protagonist to present a collection of exemplary characters. To create a complete heroic epic, the story of Geser absorbed a religious story from another culture that was very popular at the time. In the present study, five scenes common to The Epic of Geser and the Mulian story are analysed to investigate how the original Buddhist story became a part of the heroic epic. This analysis considers the ways in which identical story motifs can be used for the different purposes according to the nature of the literary work.
\end{abstract}

\section{KEYWORDS}

The Epic of Geser, Mulian Bianwen, Mulian Sutra, Mongolian heroic epic, Buddhist story, narrative modification, Tang dynasty

*Corresponding author. E-mail: storyscroll@gmail.com 


\section{INTRODUCTION}

The Epic of Geser ('Geser' henceforth) is a representative Mongolian heroic epic. It is believed that the Tibetan epic of Gesar was passed on to Mongolians and became the foundation for The Epic of Geser. The epic encompasses the birth of Geser Khan, a Mongolian hero, and his journey to becoming an absolute ruler who eliminated evil and subdued the entire universe, including heaven and earth. The Tibetan epic of Gesar, which is estimated to have been written about a thousand years ago, absorbed popular Chinese stories through trade, which in turn manifested differently in the Mongolian epic of Geser. ${ }^{1}$ Among the variations of the Tibetan epic that spread to the steppes, including Central Asia and Mongolia, the Mongolian epic remains the most intact. The present article aims to analyse a story that was popular in the Tang dynasty (618-907) and also appears in the Mongolian epic of Geser and Mulian Bianwen 目連變文 ${ }^{2}$, in which the hero saves his mother from the underworld, in comparison to the popular sutra version, Mulian Sutra 目連經. In this study, we will discuss the depiction of the scene in each of these literary works and analyse how the original story, which was evidently a Buddhist tale, was changed into a heroic story. Among the remaining texts of Geser, the best-preserved version is a Mongolian text produced with woodblock printing and published in Beijing in $1716 .^{3}$ The content analysis of Geser performed in this article primarily refers to Geser Khan (a translated Korean version of the text) and Joro's Youth: The First Part of the Mongolian Epic of Geser Khan (a translated English version of the text), which portrays Geser's childhood. ${ }^{4}$ When discussing the Mulian Bianwen, we will refer to the original Chinese version Dunhuang bianwen jiaozhu 敦煌變文校注, and the English version translated by Victor H. Mair. ${ }^{5}$ The existing texts of Mulian Sutra were mostly published during the Joseon dynasty (1392-1897) in Korea. Among them, this paper will be based on the

1 Walther Heissig estimated that the Tibetan Geser Khan epic was known to the Mongols around the end of the 16th and beginning of the 17th century, and that the worship of Geser Khan among Mongols also began at this time (Heissig 1980: 98). Until recently, the Epic of Geser was actively performed by itinerant bards. Carole Pegg visited and watched six West Mongolian artists in 1989 and 1990. Two of the artists (Getsel and Damia) sang sections of the epic 'Geser Han'. According to Pegg, the Geser epic was widespread among the Halh, Buryat, Oirad and Mongols of Inner Mongolia and the People’s Republic of China (Pegg 1995: 79-83).

2 The original title is Da Muqianlian mingjian jiumu biawen bingtu yijuan bingxu 大目乾連冥間救母變文手方 圖一卷㷏序 (manuscript number S.2614). This text was discovered in the early 20th century in Dunhuang, and the British Library in London is currently in possession of the manuscript. In this paper, Mulian Bianwen, a shortened title of the work, is used. The word 'bingtu' in the Chinese title indicates that the original work had illustrations, which must have depicted the content of the story.

3 The original title of the text is 'Arban jüg-ün ejen Geser qayan-u tuүuji orosiba' [Story of Geser Khan, Lord of the Ten Quarters]. This book is now in the National Library of Mongolia. There are currently eleven major epic of Geser block printing or manuscript versions as follows, including Beijing edition: Beijing, Longfusi 隆福寺, Utsu temple, Ordos, Beijing Library, Jamsaranno, Nomči qatan, Jay_a, Oirat tod bichig, Ling Geser, and Chengde 承德. Lee Seonggyu introduced these versions referring to the survey of Sečenmöngke and Bayaertu 巴雅爾 圖. Of these, only the Beijing edition is a woodblock print, and the rest are all manuscripts (Lee Seonggyu 2010: 172-178).

4 Yu Wonsoo (2007); de Rachewiltz and Li (2017). Both of these versions are translations of a copy of the Mongolian woodblock print from 1716, the former one being a complete Korean translation, while the latter one rendering chapter one of the total seven chapters into English. In this article, we will use the Latin transliteration of the 1716 bichig script.

5 Huang and Zhang (1997); Mair (1983). 
earliest Chinese version of Sutra of Great Mulian, Expounded by the Buddha 佛說大目連經 published in Yeongi Temple in $1536 .^{6}$

\section{Ullambana Sutra, Mulian Sutra and Mulian Bianwen}

The first story about Mulian saving his mother from the underworld originated in a Buddhist sutra called Ullambana Sutra 佛說孟蘭盆經, which was translated by Dharmarakṣa 笂法護 from Western Jin 西晉. This short sutra, which contains about 700 Chinese characters, briefly introduces the story in which Mulian pleads to the Buddha to help him rescue his mother, who has died and turned into a starving ghost. ${ }^{7}$ The story encourages readers to be kind to all creatures, faithfully offer treasure to monks, and fulfil their filial duties to their parents of the past and the present. Mulian Sutra, presumably translated into Chinese at the beginning of the Song dynasty (960-1279), appears to have been altered from Ullambana Sutra with the addition of more popular features. As the former is four times longer than the latter, the former developed a more elaborate plot and gained further narrative characteristics. The most significant difference between the content of Ullambana Sutra and Mulian Sutra is their description of the underworld. While Ullambana Sutra mentions the pain of the starving ghost in a simple and concise manner, Mulian Sutra describes the scene in greater detail.

Mulian Sutra describes the journey of Maudgalyāyana (Mulian), one of the ten disciples of the Buddha, to the underworld. The book stands out from other Buddhist scripture due to its meticulous and gripping descriptions. This literary work, with its emphasis of traditional Asian 'filial piety', became very popular in East Asia because audiences were touched by Mulian's filial act. Mulian begins his journey to the underworld with a strong conviction to save his mother, who was sent to there because of her transgressions. According to Dongjing meng hua lu 東京夢華錄, which described city life during the Song dynasty, a folk opera about Mulian saving his mother was performed from July 7 th to July 15 th of the Chinese lunar calendar. Before the Hungry Ghost Festival 中元節, the performance lasted nine days with increasing popularity, as the size of the audience continued to grow with each performance. ${ }^{8}$ Buddhist temples in Korea still host a grand-scale event called the Ullambana rite on July 15th of the lunar calendar to save the souls of the dead, promote filial piety, and prohibit the killing of creatures. Such Buddhist events and rituals are inspired by the Mulian story.

Most of the remaining Mulian Sutra were published in Korea, although they were originally produced in China. ${ }^{9}$ None of the texts remain in China at present, though a scripture titled Sutra

${ }^{6}$ Currently, this version is in the possession of the Kyujanggak Institute for Korean Studies and Korea University Library. The contents of Mulian jing, which have been utilised in this paper have mainly been sourced from original images provided by the Kyujanggak Institute.

7 The story in which Mulian saves his mother from hell first appeared in Ullambana Sutra, but other Buddhist scriptures also detailed his life. Lee Jeongjae compared the contents of these scriptures and further investigated some scriptures as the source of Ullambana Sutra. According to Lee's research, the mother-saving motif of Ullambana Sutra originated in the Pali version Peta-vetthu 餓鬼事經 and Chinese version Zhuanji baiyuan jing 撰集百緣經 (Lee Jeongjae 2019: 199-209).

8 構肆樂人, 自過七夕, 便般目連救母雜劇, 直至十五日止, 觀者倍增。(Meng Yuanlao 1957: 49).

9 On the same page of Dongjing menghua lu, Meng yuanlao mentions Zunsheng Mulian jing 尊勝目連經which was sold in the market place at that time. This scripture is likely a certain popular variant of the Mulian story that should have been very similar to the extant text of Mulian Sutra, see Berezkin 2017: 41. 
of Mulian saving his mother, expounded by the Buddha 佛說目連救母經 is held by Kyoto Konkoji Temple 金光寺 in Japan. There are currently eight documents of the Mulian Sutra in Korea, most of which were published by various temples since the middle of the Joseon dynasty. ${ }^{10}$ All of these scriptures are titled Bulseol dae Mokryeon gyeong 佛說大目連經 with the phrase “西天三藏法師 法天譯' under the title indicating that they have been translated by the Tripitaka Master Fa Tian. Since Master Fa Tian came to China from India in the early Song dynasty and participated in the translation of the Buddhist scriptures, it is likely that Mulian Sutra was brought to Korea at the beginning of the Goryeo dynasty (918-1392). These scriptures contain 18 illustrations that are significant to the history of Buddhist print. Mulian jing would have been very popular at the time because it depicts the story very vividly via illustration.

Generally, stories transform as they are narrated to audiences depending on the degree of excitement of the audience and the emotional charge of the narrator. The story of Mulian is no exception. The vivid description of his dramatic journey to the underworld, and the touching scene of a son searching for his mother all served as literary elements that helped the tale develop into a new form of a story, deviating from the original Buddhist scripture. Thus, a variety of dramatic elements were added to the pre-existing story. For example, Mulian Bianwen from the Tang dynasty can be seen as a form that incorporated such dramatic elements into a much longer and more in-depth folk stage performance. As a matter of fact, Arthur Waley, the first author to translate several Dunhuang literary works into English, stated that they were chiefly based on monkish folklore. ${ }^{11}$ Because the monks (or professional stage performers that dressed like monks) in the Tang dynasty played a key role in producing and promoting public performance, a dramatic Buddhist story such as Mulian Bianwen was, without doubt, performed by these people.

Among the Dunhuang manuscripts of bianwen works that remain today, Mulian Bianwen is the representative work of the bianwen performances that were particularly popular during the period. Bianwen is characterized by alternations between prose and verse, a verse-introductory formula, and stage performance using illustrations. These characteristics are exemplified by Mulian Bianwen. ${ }^{12}$ Although Mulian Bianwen was a popular folk narrative, it was also well-known to scholars of the Tang dynasty. This is supported by the record that two major scholars of the time, Bai Juyi 白居易 and Zhang Hu 張祜, unreservedly referred to this literary work during their conversation in Suzhou 蘇州..$^{13}$ According to the record, the scholars overlooked the common nature of the story and demonstrated their comprehensive understanding of the tale through their ability to compare each other's poems with scenes from Mulian Bianwen. Although this literary work was discovered in Dunhuang, a backwood area of northwest China, it was so popular that even scholars in the southeast city were familiar with its content. ${ }^{14}$

Mulian story is a very exciting and emotionally charged Buddhist tale that captivated the entirety of East Asia. Naturally, the content evolved into a stage performance which spread to neigh-

${ }^{10}$ Seven of the eight scriptures are woodblock prints, and the other is a manuscript, see Sa Jaedong 2000: 225-226.

${ }^{11}$ Waley 1960: 216.

${ }^{12}$ Victor Mair used a term 'prosimetric(al)' to explain this unique format that alternates between prose and verse. He also compared it with 'chantfables', a similar concept in French and argued that 'prosimetric', with a Latin root, is a more appropriate term for such a format (Mair 1989: 89-91).

${ }^{13}$ See Li Fang 2006: 1948, 'Zhang Hu'.

${ }^{14}$ Bai Juyi was especially interested in popular stories and songs. Yuan Zhen 元稹, another colleague of Bai Juyi, said in his collection of works that they have told a woman's story called Yi zhi hua 一枝花 all night long. This record indicates that Bai Juyi may have been familiar with the Mulian Bianwen, which was popular at the time, see Yuan Zhen 2000: 116, 'Lüshi 律詩. 
bouring countries. In particular, Dunhuang experienced frequent traffic from nomadic peoples and Westerners. For about 70 years from the mid-eighth century, Dunhuang was ruled by Tibet (Tubo 吐蕃). The Dunhuang manuscripts Zhangyichao Bianwen 張議潮變文 and Zhanghuaishen Bianwen 張淮深變文 describe the battle between the Tang army and the Tibetan army from the perspective of the Tang dynasty. The actual events that occurred during the period were presented in a popular form of stage performance and transformed into texts called 'bianwen'. The Chinese character 'bian 變' in bianwen refers to the transformation of the story. Additionally, the close connection between Dunhuang and Tibet during this time is supported by the large number of Tibetan manuscripts discovered in Dunhuang. It is difficult to determine when the Mulian story was introduced to Tibet. However, because Tibet's occupancy of Dunhuang and bianwen's popularity were all in the mid to late era of the Tang dynasty, we can speculate that Mulian Bianwen was introduced to Tibet during this period and was included in the Mongolian epic of Geser later.

\section{FROM BUDDHIST STORY TO HEROIC STORY: FIVE COMMON SCENES IN THREE LITERARY WORKS}

As mentioned earlier, Tibet practically ruled northwestern China from the mid-eighth century and actively exchanged culture with its neighbouring regions. During the Tang dynasty, Buddhism exerted great influence, and the northwest region of China encompassing Dunhuang, Liangzhou 凉州 (currently Wuwei 武威 in Gansu province), and Lanzhou 蘭州 was the hub of various cultures that were visited on the way to the Silk Road from Chang'an. According to the biography of the Buddhist monk Xuanzang 玄焋, merchants from the Tibetan border on the western side of the Pamir Plateau used to travel to Liangzhou in groups to attend Xuanzang's Buddhist ceremonies. ${ }^{15}$ People from the borders voluntarily came to the city located on the Silk Road route and the centre of the region to listen to Buddhist teachings. Naturally, during these active trades, Tibetan Buddhism also absorbed the local Buddhist culture. Mongolia would also have been influenced by the Buddhist culture of the Tang dynasty. However, even the same Buddhist culture was accepted differently in each culture zone. Likewise, a Buddhist story can change its nature depending on how each culture perceives and changes the story. Such modifications show the vitality and adaptability of the story itself. The present study aims to examine these aspects of adaptation by analysing several scenes in which Mulian saves his mother from hell in comparison with the counterparts in Geser. The scenes in Geser are concentrated in chapter 7, which is the last section of the story.

\section{Scene 1: The protagonist's search for his mother and discovery of her whereabouts}

- Mulian Sutra: After asking the Buddha about his mother's whereabouts, Mulian is informed that she is in the underworld.

- Mulian Bianwen: After becoming a Buddhist monk and visiting the father in heaven, Mulian is informed that his mother is in the underworld for her transgressions.

- Geser: Geser asks the deity Khormusda (Geser's heavenly father) where his mother is.

15 Beal 1914: 12. 
This scene depicts Mulian's attempt to find his mother in heaven after failing to locate her on earth. In the book of Mulian Sutra, the Buddha himself gives Mulian the information. He tells Mulian: 'Your mother was sent to the underworld when she died because she was too greedy to offer three jewels to the Buddhist monks and accumulated bad karma the size of Mt. Sumeru'. ${ }^{16}$ In the beginning of Mulian Bianwen, the World-Honoured One 世尊 informs Mulian that his mother has been sent to the underworld; in the middle of the story, his father in heaven tells him his mother's whereabouts. ${ }^{17}$ Through Buddhist meditation and supernatural power, Mulian ascends to the heavenly palace of Brahmā and asks his father where his mother is. His father has already been sent to heaven after death. This is similar to the scene in Geser in which Geser ascends to his heavenly father, Khormusda, and asks him where his mother is. Geser asks, 'Khormusda, revered god, deign to tell me whether you saw my mother's soul on the earth? - he asked. ${ }^{18}$ When he cannot find any trace of his mother on earth, he decides to visit his father in heaven to find out where his mother's soul might be because his father had always helped him in times of trouble since his childhood. In both literary works, the protagonist asks his father about his mother's whereabouts. A setting that does not exist in Mulian Sutra is found in both Mulian Bianwen and Geser; thus, there is a close connection between the two works. In other words, unlike Mulian Sutra, the protagonist in Mulian Bianwen and Geser display the behaviour of a hero who acts independently instead of passively taking in information from others. Considering that Mulian Bianwen, which was a more dramatic rendition of the original Buddhist scripture, was more popular among common people, we can assume that Geser, which was sung by minstrels, was influenced more by Mulian Bianwen regarding setting and story elements. However, this scene also points to a clear difference between the two literary works. First, the protagonist in Mulian Bianwen ascends to heaven through supernatural power he obtains through Buddhist meditation, whereas the protagonist in Geser arrives in heaven through a heroic trip. This disparity can be interpreted as the difference between a popular Buddhist story and a heroic story.

Another difference between these two plots is found in the scenes in which the protagonist acquires information about his mother's whereabouts. In the Mulian story, the protagonist first listens to the Buddha and his father before heading to the underworld to find his mother; in Geser, the protagonist descends from heaven without any special information and directly heads to the king of the underworld. In other words, there is no explanation or relevant scene describing why Geser visits the king of the underworld. The only plausible explanation is briefly given by the son of Jasa Sikir as follows: '(Your mother) acted wrongly, [her body] became covered with parasites/worms and passed away.' ${ }^{\prime 9}$ Thus, Geser ascends to heaven to locate his mother after he discovers that she has become disfigured. He then anxiously heads to the underworld after he gains nothing from his visit to heaven. Instead of depending on information from the Buddha or his father in heaven, Geser himself determines where his mother might be and descends from heaven to the underworld. This shows that Geser is a higher level of hero than Mulian. To Geser, the underworld, as well as heaven and earth, is a place he can freely visit without any obstacles.

16 汝母在生之日，不信三寶，慳貪積惡，造罪如須弥山，死入地狱中。(Fa Tian 1536: 8b).

17 爾時世尊報目連曰, 汝母已落阿鼻, 見受諸苦' ‘長者報言羅卜, 汝母生存在日, 與我行業不同 … 命 終之後, 遂墮地獄。(Huang and Zhang 1997: 1024, 1026).

${ }_{18}$ qormusta tngri aqai minu ayilad_un (=ayiladun) soyurq_a minu yirtinčü-teki (=yirtinčü-deki) eke-yin minü sünesü-yi üjebüüu (=üjebe-üü) ge üü asaүba (Geser 1716: 0702a18-0702a20).

19 (eǰei minu)... muu (=maүu) sanaju betege (=betegi) ebečin (=ebedčin) dügürčü ügei boluүsan gebe (Geser 1716: 0701a06-0701a08). 
Additionally, the two plots differ in the scene in which the protagonist first meets the king of the underworld. In Mulian Bianwen, Mulian politely asks the king about his mother's whereabouts, showing Buddhist courtesy, ${ }^{20}$ whereas in Geser, the protagonist interrogates the king of the underworld using violence and threats. ${ }^{21}$ For Geser, who has been subduing numerous enemies from heaven and earth, the underworld is just another realm in his kingdom. Thus, the leader of the underworld cannot match him. This shows that Geser has already become an active, independent, and liberated hero who is unrestrained from etiquette, religious precepts, and regulations. This shows how two different plots with almost identical narratives can be reborn in two literary works with different purposes and characteristics.

\section{Scene 2: Description of the underworld and retribution for the protagonist's mother}

- Mulian Sutra: Different images of the underworld. Mulian's mother is eating steel balls instead of food and drinking liquid copper instead of water.

- Mulian Bianwen: Mulian looks for his mother in Avīci hell, a place that shows the most gruesome scenes of the underworld. A blazing fire is spewing out of his mother's mouth and clubs are flying around. Food bursts into flame in her mouth, and water turns into hot flame even before it touches her lips.

- Geser: Geser's mother pleads for water, but she does not receive even a drop.

Mulian Sutra and Mulian Bianwen depict different scenes of the underworld. Particularly, Mulian Bianwen thoroughly describes gruesome images of those who end up there; it can be called the journey to the underworld. This part of the Mulian story is so dramatic that it is suitable for various adaptations to songs, stage performances, storytelling illustrations, and literary works. ${ }^{22}$ Further, the scenes of the underworld that Mulian passes as he searches for his mother invoke the audience's imagination of and fears about the underworld. The dead are sent to different parts of the underworld according to their karma from their previous life. For example, in knife hill and sword forest hell, people's limbs are cut off to punish them for squandering assets of or stealing from a Buddhist temple. In copper pillar and iron bed hell, men and women are tormented as their bodies are pierced with nails on an iron bed and they are tied to burning-hot copper pillars for not exercising self-control and committing adultery. ${ }^{23}$ Avīci hell is reserved for the greatest sinners who have either killed their parents or harmed the Buddha; these sinners endlessly suffer

20 貧道生年有父母, 日夜持齋常短午。據其行事在人間, 亡過合生於淨土。天堂獨有阿耶居, 慈母諸 天䚇總無。計亦不應過地獄, 只恐黃天横被誅。追放縱由天地邊, 悲嗟悔恨乃長噓。業報若來過此 界，大王繒(曾)亦得知否。(Huang and Zhang 1997: 1027).

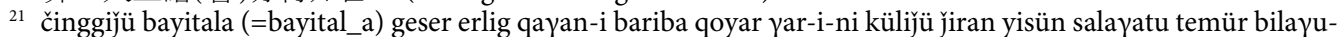
bar jančiju üdter kelejü ača ějei-yin minu sünesü qamiү_a bui ǰiүă̌u ača gebe...... (Geser 1716: 0702b240702b26, 0703a01-0703a02).

${ }^{22}$ Because of its high drama, the Mulian story has long been popular in East Asia. This may be attributed to its suitability for visual expression. For a list of major written accounts of the Mulian story in East Asia, see Berezkin 2015: 117, 'Appendix'.

23 刀山白骨亂縱横, 劍樹人頭千萬顆。… 女臥鐵床釬釘身, 男抱銅柱胸壞爛。(Huang and Zhang 1997: 1029-1030). The description of this hell in Tibeto-Mongolian Buddhist tradition is as follows: 'They are beaten into small pieces with fiery hammers and stabbed through by burning spears. They are boiled and baked like bricks and boiling iron is poured over them. Knives drop from heaven like rain. The mountains mass on each other and smash the damned.' (Mountains fall on each other), 'Getting into this hell they are laid on fiery iron 
the greatest physical pain. Readers and audiences indirectly experience such a cruel underworld and may experience a religious awakening, even if it is temporary. Without doubt, this is the main purpose of Mulian Bianwen. The indirect religious experience and thrills it provides can draw a greater crowd. Stories about visiting hell touch the audience's souls regardless of time and space. Thus, the Mulian story has been much loved across cultures and periods.

By contrast, Geser does not provide a detailed description of the underworld. Rather, the hero merely orders an old man to find his mother $^{24}$ and immediately bring her back from eighteen hells. While the journey to the underworld is the most dramatic scene in Mulian Bianwen, Geser does not describe it in detail. These two plots are similar only in the way that they describe the hero's mother: she is burned and thirsty but not able to drink any water. Unlike Mulian Bianwen, which thoroughly describes the retribution that protagonist's mother experiences, Geser does not highlight this. This also can be interpreted as a characteristic of a transition to a heroic story. This will be further discussed in the following section with 'Scene 3'.

\section{Scene 3: The protagonist rescues his mother from the underworld}

- Mulian Sutra: Mulian recites the Mahāyāna sutra and holds the Ullambana rite.

- Mulian Bianwen: Due to Mulian's earnest plea, the Buddha allows his mother to be spared from the torment of the underworld $\rightarrow$ His mother goes to Avīci hell again $\rightarrow$ Mulian recites the Mahāyana Sutra and holds the Ullambana rite.

- Geser: Khormusda invites the lamas to read the sutra.

In Mulian Sutra, Mulian's mother's bad karma is so great that she must go through many steps before she is reborn in the Trāyastrimśa palace. The last step is the Ullambana rite. In Mulian Bianwen, Mulian's mother is allowed to leave the underworld after Mulian pleads to the Buddha, begs for food and water, recites Mahāyāna sutra 大乘經, and holds the Ullambana rite. In the end, she is reborn first as a dog and later as a human. ${ }^{25}$ In contrast, in Geser, 'Revered god, Khormusda invited Lamas from the ten directions, made them pray for calling [his mother's] soul; meanwhile, her soul transformed into innumerable buddhas. ${ }^{26}$ Geser had already arranged to send his mother's soul to his father. Because Geser is a heroic epic, this scene highlights the absolute power of the hero. On the other hand, the Mulian story focuses on sins and Buddhist acts as a way to resolve these instead of focusing on the protagonist. In this light, rescuing the mother in Geser goes smoothly according to Geser's plan, whereas saving his mother in Mulian Bianwen requires many long and laborious steps. The difference in the description of the underworld in Scene 2 (thoroughly detailed in the Mulian story but hardly described in Geser) can be interpreted in

plates, and suffer of thirst and hunger. Burning iron is put to their mouths. Escaping from this hell they are reborn for seven thousand births as preta-s, then for seven thousand births as animals that do not find food.' (Iron pressing), see Bethlenfalvy \& Sárközi 2010: 14-15.

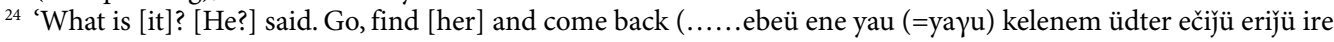
gebe.....; Geser 1716: 0703a18-0703a19).

25 The scripture and popular narrative differ in the way they deal with Ullambana rite. In canonical sources, the establishment of the ghost festival constitutes the climax of the story, but the bianwen includes the festival almost as an afterthought-as one more device included hurriedly in the denouement after the Buddha has already rescued Qingti from Avīci hell (Teiser 1996: 177).

26 ......qormusta tngri aqai-ni arban jüg -eče lam_a-nar-i uriǰu irejuü sünesü-yi ni jalaju nom ungsi (=bayital_a) ekei (=eke) ni sünesün-i to $\gamma \_a$ tomsi ügei olan burqan bolba ...... (Geser 1716:0704a12-0704a16). 
the same vein. In other words, the focus gradually shifts from Buddhist content to heroic acts in Geser. This can be seen as a transition from a Buddhist story to a heroic story. To put it differently, the conflict and issues are similar, but the process and agency change from a religious colour to a heroic colour.

This does not mean that stories about the underworld were not popular in Mongolia. Multiple Mongolian block prints describe the cruel underworld alongside illustrations, which present a vivid image of the underworld with short Mongolian captions in the margins. ${ }^{27}$ These illustrations of the underworld are based on the Buddhist Bhavacakra, and they are a typical part of the tradition of Buddhism. The story of Molon toyin's (i.e., Mulian's) visit to hell seems to have been quite popular in the traditional era Mongolia. ${ }^{28}$ Based on Lörincz and Heissig's linguistic studies, it is reasonable to assume that the story of Molon toyin was first translated into Mongolian at the beginning of the 17 th century at the earliest date. ${ }^{29}$ In other words, the story of Mulian was translated about 100 years before the epic of Geser was translated and published in Mongolian. Therefore, it is important to note that Buddhist story and heroic story existed as two different traditions in Mongolia. These different traditions influenced each other while maintaining their own characteristics. Since the Mulian story was very popular in Mongolia, a dramatic part of it was included in the epic of Geser. In this process, the traditional elements of the story were gradually diversified. The underworld stories were expressed differently within these two traditions. Although underworld stories existed in the Buddhist tradition connecting Tibet and Mongolia, some of the motifs might have undergone the process of selective integration with Mongolian heroic epics, with greater emphasis on the heroic epic. What was essential in the Buddhist tradition became secondary in heroic epics. This may be seen as the weakening of the Buddhist characteristics of the original stories, but it can be also conceived of as an adaptation to a different tradition.

Such an adaptation can also occur in the opposite case: a well-known hero can be brought into a religious story to highlight religious traits, changing the original story into another story full of religious elements. This trend is visible in the Dunhuang manuscript of Han Qinhu huaben 韓擒虎話本. ${ }^{30}$ Han Qinhu, who was a war hero during the Sui dynasty (581-618), was brought into a Buddhist literary work although he did not have any special connection to Buddhism. As such, the alteration of the story's nature was possible because of demand; according to this logic, stories can expand without limitations. Such expansions cross different cultural zones, and that is the power of a story. Without doubt, there are a few pre-requisites for such expansions to occur. First, the content of the targeted story must be interesting enough to move people. Second, the original traits of the story's characters must fit into other stories. Mulian in Mulian Bianwen was

27 See Bethlenfalvy \& Sárközi 2010.

28 In earlier studies, Sárközi introduces the 19th century Mongolian picture book of Molon toyin's descent into hell. He proposes that this book comes near to every-day life as far as its theme and presentation are concerned. There is a fresh breath in these pictures-the world they depict is not any longer Chinese or Tibetan but Mongolian. On the basis of illuminated texts from Tang dynasty China and Tibet, he supposed that the Molon toyin story, as well as the custom of depicting popular, partly religious tales in picture-book form came into Mongolia from China, though it was also well-known in Tibet (Sárközi 1976: 275-277).

${ }^{29}$ See Chiodo 2009: 172.

${ }^{30}$ It appears that a religious illustration was intended to be on the front page of the remaining Dunhuang manuscript of Han Qinhu huaben before binding. This indicates that they took into consideration the readers who preferred a copy with religious illustrations (Jung Kwanghun 2009: 26-29). 
an inspiring figure suitable to be replaced by the image of Geser, just as Han Qinhu in Han Qinhu huaben was a war hero suitable to become a Buddhist character. ${ }^{31}$

\section{Scene 4: The reason the protagonist's mother is sent to the underworld}

- Mulian Sutra: Mulian's mother was too greedy to offer three jewels and accumulated bad karma the size of Mt. Sumeru.

- Mulian Bianwen: Mulian's mother was unkind to people, committed evil acts, and recklessly killed creatures.

- Geser: Geser's mother tried to bury Geser Khan in eighteen pits when he was born.

This part of the story clearly shows the alteration of a Buddhist story into a heroic story; the protagonist himself is not only the source of the conflict, he is also the agent who solves the problem. According to the Buddha in Mulian Sutra, the reason that his mother, Lady Qingti 青提夫人, was sent to the underworld is that she was too greedy to offer three jewels and accumulated evil deeds the size of Mt. Sumeru. In other words, she was sent to the underworld for religious reasons. In Mulian Bianwen, Lady Qingti commits a great deal of sin in her lifetime. Holding the gate of hell, she tells her son: 'In the old days, your mother behaved avariciously, I failed to provide myself with grace for the karmic retribution of the next life; The things which I said deceived heaven and denied hell. I slaughtered pigs and goats on a grand scale to sacrifice to ghosts and spirits.' ${ }^{32}$ She violates so many Buddhist precepts that she suffers in many different hells. In contrast, in Geser, the hero's mother is sent to the underworld because 'When Geser Khan was born, his only birth mother did not know whether [the child] was a buddha or an evil; therefore, she dug a hollow of 18 -fathom length and threw him into it. ${ }^{33}$ She was punished not because she committed evil from a Buddhist perspective, but because she attempted to kill Geser Khan, who was about to become a hero. Although the ultimate result of her evil deeds is the same, the cause is different.

The fact that she almost committed murder because she was not sure whether her son was a devil or a Buddha shows that Khan's mother worshiped the Buddha. Geser himself led his mother to fall into the underworld. This shows a glimpse of the possibility that the story could be altered into another type of epic apart from a Buddhist story. In other words, it implies that Geser can become a hero who is essentially different from the Buddha. This is in line with the earlier discussion that Geser is gradually drifting away from Buddhist features, unlike the Mulian story. As

31 Heissig once analysed a novel from the Ming dynasty called Hua guansuo zhuan 花關索傳 in comparison to Mongolian epics and nineteenth-century eastern Mongolian oral prosimetric traditions (Bensen üliger) in terms of similar narrative motifs. Heissig introduced the 'companions with extraordinary powers' motif and mentioned that the motif found in 'Bianwen (Transformation Texts)' was preserved for over 600 years and remains in the literary works in China and Mongolia. As an example of Bianwen, he used Han Qinhu Huaben. Among many Bianwen works, motifs of Mulian and Han Qinhu were revitalized several hundred years later in Mongolian culture, which cannot be seen as a simple coincidence. See Heissig 1994: 241-242, 248 , note 4.

32 “孃孃昔日行堅妒, 不具來生業報因。言作天堂沒地獄, 廣殺豬羊祭鬼神。' (Huang and Zhang 1997: 1034). The translation is based on Mair 1983: 111.

33 ......geser qaүan törökü ča $\gamma$-tu ġag̉ša amuř̌ila ekeni (=eke-ni) čidkür buyu burqan buyu gejü ese medejü arban naiman alda $\gamma$ uu uquju tere $\gamma u u-t u r(=\gamma u u-d u r)$ orkiy_a gegsen (Geser 1716: 0704b12-0704b15). When Geser was born, his mother cursed him, deeming him to be an evil child. This was because her little finger froze while she was trying to cut his umbilical cord in the cold rain. Thus, she felt as if this child was a devil. She had no other choice but to give birth to this child in such a harsh environment, and this put the hero in an uneasy position from the moment of his birth (Stein 1959: 543). 
mentioned earlier, a smooth resolution of conflicts became possible through Geser Khan, and the initial cause of the conflict was with the hero, Geser Khan. In fact, the beginning of Geser includes a scene in which Geser's mother curses her son in a very heart-breaking way as soon as the boy is born. The mother realizes that she cannot afford to raise four children and decides to bury them alive as soon as they are born. However, the first three sons were incarnations of the Buddha and went their ways under the guidance of the heaven above, the dakinis of the Ten Regions, and the dragon king. She believed that her three sons, who died as soon as they were born, were called by the Buddha. She curses the last son to be born as the incarnation of the devil, who was not called by the Buddha. She tries to bury him in the pits she has already dug. However, in the end, her husband, Sanglun, convinces her to keep the boy. ${ }^{34}$ As such, the story about Geser's birth is placed at the beginning and the end of the entire epic. This must have been perceived as a very familiar and dramatic scene by the audience. The conflicting relationship between Geser and his mother was designed to be solved completely by Geser at the end; he saves his mother's soul from the underworld and turns her soul into many Buddhas. In this process, we can see a heroic image of Geser. All scenes are centred on the hero: the reason his mother is sent to the underworld, his journey searching for her, and, ultimately, resolving the conflict.

\section{Scene 5: Description of the main characters}

- Mulian Sutra: Brief introduction of Mulian and detailed description of his mother's evil deeds.

- Mulian Bianwen: Relatively brief mention of Mulian's mother's evil deeds.

- Geser: Descriptions focused on the hero, Geser.

The descriptions of the main characters in these stories also differ. These differences are notable because they indicate the transition from a Buddhist story to a heroic story. In the early part of Mulian Sutra, the introduction of the protagonist Mulian is brief, whereas the evil deeds of Mulian's mother are described in great detail despite the length of the story. This is because his mother was sent to the underworld due to her repeated evil deeds; from a Buddhist point of view, the evil deeds had to be described in full. Due to the philosophy of causation in Buddhism, the reason one enters a certain world after death is more important than the description of the world itself. Good karma and bad karma are accumulations of such causes; thus, the description of Mulian's mother's deeds leads to her being sent to the underworld. Nevertheless, Mulian Bianwen demonstrates different characteristics in this section. Although Mulian's mother is sent to the underworld for the same reasons, the description of her evil deeds is unexpectedly simple. In contrast, the protagonist Mulian is described in great detail, including his entering the Buddhist priesthood, performing penance, being enlightened by Buddhist truth, and obtaining supernatural power. The story still has very religious elements, but Mulian Bianwen shows the image of the protagonist gradually becoming a religious hero. Although they are both Buddhist tales, Mulian Sutra as a scripture highlights the evil deeds of the mother while Mulian Bianwen shifts its focus

${ }^{34}$ See de Rachewiltz and Li 2017: 36-37.......tede bügüde-yi tuүulamaǰi-ni činggijü ečibe. ab odo muu (=maүu) kültügür čidkür-yin (=ün) qubil үan keüken törömeǰin-i (=törömeǰin) namai (=namayi) bariǰu idey_e gěü inggij̆ü bayinam gebe. ebügen kelebe. ebeü či čidkür -yin (=ün) qubil ${ }^{2}$ an-i yeyijü (=yayakijuu) medebe či. demei taүaǰu medekü. bide burqad buyu. öber-ün ür_e-yi yeyij̆ü (=yaүakiǰu) alam teǰiyejü [teǰigejü] üǰey_e...... (Geser 1716: 0111b05-0111b12). 
onto Mulian himself. Mulian Bianwen's focus on a certain character shows that it already had the necessary elements for becoming a heroic story. Geser emphasises Mulian's heroic side, bringing this image to the original heroic epic. The heroic characteristics of Mulian become a part of the heroic image of Geser. Accordingly, this alteration of the protagonist's images reveals the process through which a Buddhist story gradually becomes a heroic epic. This alteration is directly related to the purpose of the Mongolian Geser epic. Pegg notes that, 'In the Tibetan version of the epic, Geser is depicted as a Buddhist hero whose purpose is to defend the faith against non-believers. But in Mongolian versions, Geser is sent to earth by his father, Hormusda, the ruler of the heavenly beings (tengri), to free the earth from evil rather than to defend Buddhism. ${ }^{35}$ That is, the Tibetan protagonist and Mongolian Geser demonstrate completely different features concerning Buddhist elements. The two lines of tradition also differ regarding the purpose in Geser's acts. The difference in the description of the main characters reflects the difference in the traditions in Tibet and Mongolia regarding Buddhist elements.

\section{COMPLETION OF THE HEROIC FIGURE: GOVERNING THE UNDERWORLD}

An investigation of Geser's birth and his family tree shows that he was destined to become a hero. Geser was the son of heaven, Khormusda; in obedience to the Buddha's command to save the human world from chaos, he was born to a woman named Gegshe Amurchila. To resolve the crisis on earth, heaven makes his son be born in a human body. In other words, before Geser's birth, he is chosen as a figure that can govern both heaven and the human world, with the blessings of the Buddha. It is noteworthy that Geser's three other brothers born to his mother each represent three worlds: heaven, the underworld, and the Ten Regions. For Geser to overcome the conflict with his mother, who tried to abandon him and to represent the whole universe, he should be able to control all three worlds. However, the worlds that are directly related to Geser's heroic acts are heaven and earth or the human world. In this epic, Geser Khan plays an active role in the realms of heaven and earth, not in the underworld. Geser's family tree is also spread among heaven and the human world. He has a heavenly father, mother, and brothers separately from his earthly father, mother, and brothers. Geser thus becomes a mediator between the two worlds. The remaining world that has no direct connection to Geser is the underworld. To become a complete hero, Geser needed to govern the underworld as well.

In Geser, the king of hell (lord of the underworld) appears in several scenes. In the first scene, he is mentioned after Joro (young Geser) has a physical fight with Chorisdong Lama. When Joro throws Lama off his horse, his uncle Chargin, who is more cool-headed, scolds him for his rude behaviour toward his in-law. Joro listens to his uncle and lets Lama go by saying:

'I release you because of uncle Chargin's words, but be sure that either in this world before the multitude of men, or in the netherworld before the King of Hell I shall disgrace you and bring shame on you!'36

35 Pegg 1995: 95.

36 Trans. de Rachewiltz and Li 2017: 65. .......̌̌argin abayai-yin ügeber (=üge-ber) talbiy_a. ai čamai (=čimayi)

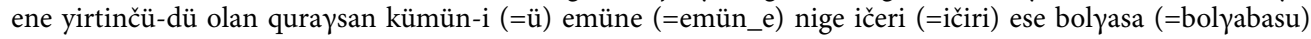
bi qoyidu yirtinčü-tü (=dü) erlig qayan-i tende nige ičeri (=ičiri) ese bolyasa (=bolyasai) bi ged talbiba. (Geser 1716: 0130b24-0130b26, 0131a01-0131a03). 
Joro thus warns Lama that he will disgrace him either on earth or in the underworld. Later, Joro challenges Lama for supernatural power and teaches him a lesson. In this scene, the spatial background of beating him to the end was not the underworld but earth. As a ruler whose blood lineage comes from heaven, Joro defeats Lama easily without having to go down to the underworld. In the next scene, he is horse-racing with 30,000 people, according to Chotong Noyan's plan. Chotong Noyan is Geser's uncle and enemy. Joro prays to his heavenly grandmother, Absa Kürje, as follows:

'Grandmother of mine! It was in order to help all the creatures in this world that I was born as Geser Khan, Lord of the Ten Quarters. It was in order to deliver from suffering the souls of all the sinners doomed in the hereafter to the realm of Erlig Khan that I was born as Khangkhui Köbegün. ${ }^{37}$

In Mongolian, 'Erlig Khan' means the king of the underworld or judge of the dead. Young Joro has not been to the underworld, which is reserved for the dead. Nevertheless, Joro is fully aware of the existence of the underworld as well as his responsibility there.

The third scene shows Geser's wife, Rogmo Gowa, pouring her heart out to her mother-in-law about Geser's harsh treatment and telling her about her plans to plead to Erlig Khan when she dies.

'Oh mother dear, for so long now I have been suffering in all possible ways because your son is not living with me in the accustomed way-as husband and wife do. It would be better for me to die rather than keep on suffering thus. I shall make a complaint about it to Erlig Khan! The white of my eyes has grown yellow, the black of my eyes has turned pale!'38

When Rogmo Gowa complains, Geser brags of his achievements as Khan for the last fifteen years from his birth. With this scene in which Joro celebrates becoming Geser Khan, a ruler of the universe, the first chapter of Geser, which is mainly about Geser's childhood, comes to an end. As shown above, Geser was aware of the underworld from his childhood, but the commands from heaven and his achievements on earth made him a mature Khan. At this point, Geser was not quite ready to rule the underworld.

After Geser becomes Khan, he kills his strongest enemy, Mangus, and defeats the most powerful enemy territory, the Sirayijol territory. In Geser, the course of the battle and defeat is described very vividly; this is the main content of the epic. Particularly, the scene in which Geser plans to kill Mangus and carries out his plan is the climax of the story. Geser receives much help here from heavenly figures as well as from the human world. Nevertheless, Geser's heroism is ultimately confirmed by his rulership of the underworld. He must prove that he can enter the world of the

37 Trans. de Rachewiltz and Li 2017: 79. ......ejei minu ene yirtinčü-dü qamuү amitan-i tuslaqu-yin tulada arban jüg-ün eǰen geser qaүan bolun törölüge bi. Qoyidu jiyajan-tu (=du) erlig qaүan-u tende kilinče-den (=kilenčeten) bügüde-yin sünesün-i tonilyaqu-yin tulada qangqui köbegün bolun törölüge...... (Geser 1716: 0139b26, 0140a01-0140a05).

38 Trans. de Rachewiltz and Li 2017: 91. ......ai eǰei tedüi-eče edüi kürtele (=kürtel_e) ali büri inggiǰi (=inggǐüu) jobam bi. čini (=činu) köbegün činu nadala (=nada-lu $\left.\gamma \_a\right)$ ǰüger yabuqu ügei jobaǰi (=jobaju) yabuqui-ača ǰokiǰi


(Geser 1716: 0148a16-0148a21). 
dead without dying and rule there. His rulership of the underworld also differentiates him from his strongest opponent, Mangus, the twelve-headed monster. Mangus, who frequently commits evil acts while traveling between heaven and earth, is powerful enough to steal Geser's wife, Aralu Gowa. However, he is not capable of ruling the underworld. In the early 1960s, a Mongolian singer named Pajai (1902-1962) recorded a song with the title 'The Twelve-headed Monster' based on the epic of Geser as follows: ${ }^{39}$

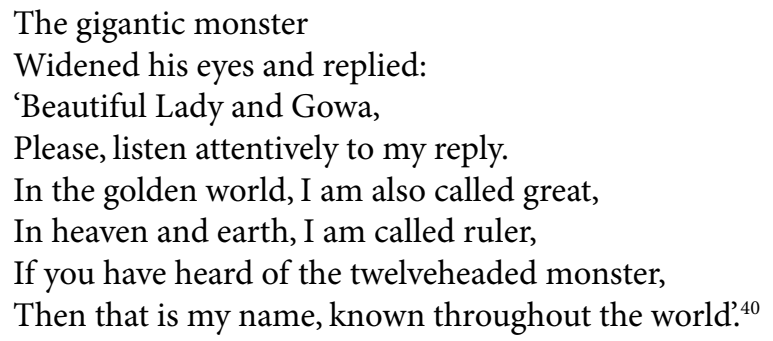

In this scene, Mangus introduces himself when Aralu Gowa fearfully asks who he is. As the lyric shows, Mangus calls himself a ruler of heaven and earth, but he does not mention the underworld. The only figure that can rule the entire universe including the underworld is Geser. This distinctive nature gives him the context to defeat powerful opponents. Unlike regular folktales, legends, and myths, all episodes in heroic epics ultimately focus on one hero. The opponents who appear to be more powerful than the hero are incomplete figures in reality. ${ }^{41}$ This is confirmed as the epic unfolds. The plot of epic tales-which consists of the hero's childhood during which he shows a glimpse of his heroic nature; young adulthood during which the hero obtains more heroic attributes as he defeats numerous enemies; and his final completion of heroic acts by conquering the underworld-is exciting enough to fascinate the audience. Audiences of epics pay attention to such plots and fully experience catharsis.

\section{INTENTIONAL ACCEPTANCE OF THE MULIAN STORY MOTIF AND RE-CREATION}

As discussed above, in order to create a complete image of a hero who rules the entire world, Geser needed to be victorious in the underworld. In this regard, the Mulian story in which Mulian saves his mother from the underworld is the ideal motif to complete the plot in Geser. When Geser cannot find his mother's whereabouts on earth, he ascends to heaven to find the information. He eventually goes to the king of the underworld. To solve the problem, he travels to heaven, earth, and

39 In 1959, Kara visited Inner Mongolia and collected 29 songs from Pajai. Among them, 1-5 items belonged to the Geser epic. Sometimes Pajai quoted the Beijing version of the Geser epic published in 1716 almost wordby-word (Kara 1970: 186).

40 Mair and Bender 2011: 219.

${ }^{41}$ As Geser is an absolute being, he deserves the reverence of a god. According to Yang Enhong's survey of Mongolian epic singers, there is a popular saying among Mongolians: any story is easier to tell than that of Geser. This is because they believe Geser to be a god, and therefore sublime and not to be spoken about casually. The Mongolian artist Blobsang investigated by Yang had to sit straight, covering his legs with his Mongolian robe, and could not cross his legs, smoke, or drink alcohol when he sang the Geser epic. Usually, he did not dare to even mention the name of Geser lest the King overhear him and grow angry (Yang Enhong 1998: 425). 
the underworld. The image of Geser ruling the entire world was necessary to complete the heroic epic. In doing so, Geser becomes a complete hero figure who controls the entire universe including the underworld; along the way, he resolves the conflict with his mother that arose from his birth against his will. As a heroic figure, he should be able to solve all problems in heaven, on earth, and in the underworld. Thus, the overall heroic epic was completed by appropriating the Mulian story.

The story of Geser saving his mother from the underworld gives the impression that a new story was inserted at the end of the entire epic. For example, unlike previous episodes, this part of the story starts with 'one day', which is frequently used when the story is changed. In order to reach the smooth completion of this story following this awkward shift in the narrative, a new story emerges to fill in the gap that has been created by previous episodes. The heroic image of Geser is completed by the image of Mulian through a story involving control over the underworld that derives from Mulian Bianwen. ${ }^{42}$

The image of Geser's mother plays a significant role in the intentional acceptance of the Mulian story motif. Geser's mother is mostly mentioned in the beginning section that describes young Geser and then in the underworld at the end of the epic. His mother is not mentioned once during the battles in which Geser kills Mangus and Geser's soldiers fight enemies from the Sirayi $\gamma$ ol territory; however, when Geser returns to his family nine years later, she is mentioned again. The scene in which Geser's mother wonders if he is her son, unable to dare to call him son after years of his absence, creates a sense of compassion and sadness among the audience. The mother has not forgotten her sin of attempting to bury her child, and people feel sympathy towards her. This part of the story provides the audience with a rightful cause for Geser to rescue his mother from the underworld. The image of Geser leaving his mother to fight his enemies overlaps with the image of Mulian leaving his mother for business. While Geser and Mulian are away from their mothers, their mothers are sent to the underworld. Shocked by his mother's death, Mulian pleads to the Buddha after completing his three-year-long filial duty for his mother and gains supernatural power, which serves as the foundation for his rescue of his mother. Likewise, Geser returns from his long journey after battles and saves his mother from the greatest crisis, returning his favour to his mother. The story of Mulian, a man who becomes a monk and saves his mother from the underworld, served as the perfect motif for the relationship between Geser and his mother.

\section{CONCLUSION}

Heroic epics can be understood as a collection of exemplary characters. Heroes are perfect figures that must be outstanding in all senses. Accordingly, numerous tales are required for the composition of a complete heroic epic. In this process, pre-existing stories are modified to fit the overall plot and nature of the epic. To create a perfect heroic epic, the Epic of Geser absorbed and changed a religious story from another culture that was popular at the time. To highlight the heroism of the protagonist, who controls all of the world, Geser used content involving the underworld from the story of Mulian, which appears in the Buddhist scripture as well as bianwen, which was popu-

${ }^{42}$ In other parts of Geser, we can also find traces of new stories that were added to increase public interest in the epic. In this regard, Louis Ligeti has focused on an episode, which is concerned with the Chinese origins of Geser. He claims that the story of 'Banqiao Sanniangzi 板橋三娘子' in Taiping guangji 太平廣記 is the origin of the episode of 'Geser who became a donkey', seen in Chapter 6 of Geser, analysing these two works in terms of their language and history oral tradition (Ligeti 1951:347-351). 
lar in Dunhuang and much longer than the scripture. Mulian Bianwen not only presents the story of the underworld but also the heroism of the protagonist. This is an example of the modification of a religious story into a heroic epic.

In the history of ancient Chinese literature, the Tang dynasty stands out as a period in which the volume of diverse stories rapidly increased. Even among scholars, there was a prevalent trend of adapting and re-writing popular tales of the time in one's own style. Among common people, literary works that had originally been vernacular narratives were also very popular. Moreover, the Tang dynasty frequently traded with neighbouring ethnic groups through the silk road. Of all Chinese dynasties, the Tang dynasty had the greatest influence on its western border. Even royal families had mixed blood lineages with northern nomadic nations. This context allowed active exchanges with foreign cultures. Under such historical circumstances, diverse stories from different cultural zones could be naturally modified, mutually influencing one another. The Epic of Geser, the Mongolian hero epic, is the significant fruit of such exchanges.

\section{ACKNOWLEDGMENTS}

This work was supported by the Ministry of Education of the Republic of Korea and the National Research Foundation of Korea (NRF-2019S1A5B5A02046123). This work is supported by Hankuk University of Foreign Studies Research Fund. We would like to express our gratitude to the anonymous reviewers of Acta Orientalia Hung. for providing invaluable advice and additional references. We are also grateful to Professor Lee Suna and Professor Agnes Birtalan for interpreting the original Mongolian text.

\section{REFERENCES}

Arban jüg-ün ejen Geser qayan-u tuyuji orosiba [Story of Geser Khan, Lord of the Ten Quarters] (Mongolian woodblock print in the possession of the National Library of Mongolia) 1716. Beijing.

BEAL, Samuel (trans.) 1914. The Life of Hiuen-Tsiang (by the Shaman Hwui li 慧立). London: Kegan Paul Trench Trubner \& Co. Ltd.

Berezkin, Rostislav 2015. 'Pictorial Versions of the Mulian Story in East Asia (Tenth-Seventeenth Centuries): On the Connections of Religious Painting and Storytelling. Fudan Journal of the Humanities and Social Sciences 8/1: 95-120.

Berezkin, Rostislav 2017. Many Faces of Mulian: The Precious Scrolls of Late Imperial China. Seattle and London: University of Washington Press.

Bethlenfalvy, Géza and Alice SÁrközi 2010. A Tibeto-Mongolian Picture-Book of Hell. [Treasures of Mongolian Culture and Tibeto-Mongolian Buddhism 5.] Budapest: Institute of Ethnology Hungarian Academy of Sciences.

Chiodo, Elisabetta 2009. The Mongolian Manuscripts on Birch Bark from Xarbuxyn Balgas. [Collection of the Mongolian Academy of Sciences Part 2.] Wiesbaden: Harrassowitz Verlag.

FA Tian 法天 (trans.) 1536. Bulseol dae Mokryeon gyeong 佛說大目連經 [Mulian Sutra, Expounded by the Buddha]. Gochang: Yeongi Temple.

Kara, György 1970. Chants d’un Barde Mongol. Budapest: Akadémiai Kiadó. 
HeIssig, Walther 1980. The Religions of Mongolia. [Trans. Geoffrey Samuel.] Berkeley and Los Angeles: University of California Press.

Heissig, Walther 1994. 'Tracing Some Mongol Oral Motifs in a Chinese Prosimetric Ming Novel of 1478.' Asian Folklore Studies 53/2: 227-254.

Huang Zheng 黃征 and Zhang Yongquan 張涌泉 1997.Dunhuang bianwen jiaozhu 敦煌變文校注 [Collations and Annotations of Dunhuang Bianwen]. Beijing: Zhonghua shuju.

Jung Kwanghun 鄭廣薰 2009. 'Dunhuangben 'Hanqinhu huaben' de xiejuan zhizuo fangshi he wenxue tedian 敦煌本《韓摛虎話本》的寫卷製作方式和文學特點 [The Making of Dunhuang Manuscript Scroll ‘Hanqinhu Storytelling Script' and its Literary Features]. Yishu baijia 藝術百家 2009/2: 25-32.

Lee Jeongjae 이정재 2019. 'Mokryeon gumo seolhwa ui chogi hyeongsunge daehan sogo 目連救母 說 話의 초기 형성 과정에 대한 小考-초기 불교 문헌들과 佛說 孟蘭盆經의 비교를 중심으로' [A Study on the Early Formation of the Story of Mulian Rescues his Mother: Focused on the Comparison between Early Buddhist Texts and the Ullambana Sutra].' Jungguk eomun nonchong 中國語文論 叢 95: 183-213.

LEE Seonggyu 이성규 2010. 'Monggol Geser yiyagiui panbon gwa ganhaeng 몽골 게세르 이야기의 판본 과 간행 [A Publication and Edition of Mongol Epic Geser]'. Monggol hak 몽골학 2010/30: 169-190.

Li Fang 李昉 et al. 2006. Taiping guangji 太平廣記 [Extensive Records of the Taiping Era]. Beijing: Zhonghua shuju.

Ligeti, Louis 1951. 'Un épisode d’origine chinoise du “Geser-qan”'. Acta Orientalia Hung. 1/2/3: 339-357.

LőrInCZ, László (ed.) 1982. Molon Toyin's Journey into the Hell. Altan gerel's Translation. [Monumenta Linguae Mongolicae Collecta VIII.] Budapest: Akadémiai Kiadó.

MaIr, Victor H. (trans.) 1983. Tun-huang Popular Narratives. New York: Cambridge University Press.

MaIR, Victor H. 1989. T'ang Transformation Texts: A Study of the Buddhist Contribution to the Rise of Vernacular Fiction and Drama in China. Cambridge (Mass.) and London: Harvard University Press.

Mair, Victor H. and Mark Bender (ed.) 2011. The Columbia Anthology of Chinese Folk and Popular Literature. New York: Columbia University Press.

Meng Yuanlao 孟元老 1957. Dongjing meng hua lu 東京夢華錄 [The Eastern Capital: A Dream of Splendor]. Shanghai: Gudian wenxue chubanshe.

PegG, Carole 1995. 'Ritual, Religion and Magic in West Mongolian (Oirad) Heroic Epic Performance.' British Journal of Ethnomusicology 4: 77-99.

de Rachewiltz, Igor and LI Narangoa (trans.) 2017. Joro's Youth: the First Part of the Mongolian Epic of Geser Khan. Canberra: ANU Press.

SA Jaedong 사재동 2000. 'Mokryeongyeong ui yujeon gwangye 目連經의 流轉關係' [A Research on the Dissemination of Mulian Sutra].' In: SA Jaedong (ed.) Uranbunjae wa Mokryeon jeonseung ui munhwa$s a$ 孟蘭盆齋와 目連傳承의 文化史 [Cultural History of the Ullambana Ritual and Dissemination of Mulian story]. Daejeon: Joongang Inmunsa, 211-232.

SÁrközI, Alice 1976. 'A Mongolian Picture-book of Molon Toyin’s Descent into Hell'. Acta Orientalia Hung. 30/3: 273-308.

Stein, Rolf Alfred 1959. Recherches sur l'épopée et le barde au Tibet. (Thèse pour le doctorat des lettres, Faculté des lettres de l'université de Paris).

Teiser, Stephen F. 1996. The Ghost Festival in Medieval China. Princeton: Princeton University Press.

Waley, Arthur 1960. Ballads and Stories from Tun-huang: An Anthology. New York: The Macmillan Company.

YANG, Enhong 1998. 'A Comparative Study of the Singing Styles of Mongolian and Tibetan Geser/Gesar Artists.' Oral Tradition 13/2: 422-434.

Yu Wonsoo 유원수 (trans.) 2007. Monggol daeseosasi Geser Khan 몽골 대서사시 게세르 칸 [Mongolian Epic Geser Khan]. Seoul: Sakyejul Publishing Ltd.

YuAn Zhen 元稹 2000. Yuan Zhen ji 元稹集 [Collected Works of Yuan Zhen]. Beijing: Zhonghua shuju. 
Open Access. This is an open-access article distributed under the terms of the Creative Commons Attribution-NonCommercial 4.0 International License (https://creativecommons.org/licenses/by-nc/4.0/), which permits unrestricted use, distribution, and reproduction in any medium for non-commercial purposes, provided the original author and source are credited, a link to the CC License is provided, and changes - if any - are indicated. 